\title{
Empowerment of Women Teachers in Improving Quality of Education in the 25 State Junior High School Sarolangun
}

\author{
Norainun \\ Magister Candidate (S2) padaInstitut Agama Islam NegeriSulthanThahaSaefuddin(IAIN STS) Jambi
}

\begin{abstract}
A lack of effort from the headmaster in the empowerment of women teachers in Junior High School 25 Sarolangun, good empowerment additional positions, training, and other activities in junior high. That is the empowerment of female teachers in SMPN 25 Sarolangun still be discriminated against on the principal itself. Therefore, in the face of MEA female teachers must be empowered and equal with male teachers. In addition, the principal must cooperate with local and provincial governments in order to empower women teachers in any field to match the capacities and skills of women teachers themselves
\end{abstract}

Keywords: Women's teachersEmpowerment, the Education Quality

\section{Introduction}

Etymologically, the word comes from the empowerment of power, which means the ability to do something or the ability to act. Got prefix Air-be "empowered" means strength, capable, powerful, have the sense (the way and so on) to overcome something (Suparno: 2014). Tjiptono the quotation by Kadarisman (2013), defines empowerment is an effort to provide autonomy, trust superiors to subordinates, and to encourage them to be creative in order to finalize its work as good as possible. Employees were given the freedom to take actions deemed appropriate in order to serve its customers, including the handling of their complaints. Through employee empowerment, is expected to occur sharing of power, which subordinates are involved together with the management to make changes.

Cluttebuck opinion of the quotation by Maisah (2013), that empowerment is as: 1) a new way to provide the ability for employees who need to finish the job, 2) designation of responsibility in decision making up to the management level at the bottom, 3) granting powers of control of top management to employees for the benefit of the organization as a whole, 4) creation an atmosphere in which employees can use the full capability to achieve organizational goals, 5) psychological energy that makes employees more active. To make empowerment a reality in the workplace, the following matters: 1) gives the opportunity to grow, 2) the responsibilities, 3) distribute authority, 4) make subordinates accountable5) provide the ability.

Related to the empowerment of female teachers is one form of attention and motivation of both the government and of the principal itself to his teacher as 1) the empowerment of women teachers through teaching duties, 2) Empowerment of women teachers improve competence qualification bachelor, master, doctoral, 3) empowerment of teachers additional supplemental positions women, 4) Empowerment of women through training teachers, 5) teacher empowerment of women through various activities to improve the quality of education
According to Nanang (2013) quality is the qualities of a product or service that can meet the needs or expectations, customer satisfaction education. Meanwhile, according to Edgar 91 992) quality (quality) on profit organization is "Doing the right thing, right time, always strings for improvement, and always satisfying the costumers". The Irianto (1997) mentions the same quality and customer satisfaction, but it turns out the concept of quality is not as simple as that because of the quality at an early stage and should be done if you want to start the achievement of quality.

To achieve the quality standards mentioned above, cannot be separated from the cooperation of the various parties involved in education in general, and in particular the cooperation the head of Junior High School 25 Sarolangun, teachers both male teachers and female teachers, staff and the people in the vicinity. Therefore, to realize the improvement of the quality of education, LiasHasibuan (2008) quotes John I. Goodlad income, required an innovation in four forms: (1) Identifying the various factors that influence the quality improvement of education in the context of school, (2) The appearance of a change strategy that is executed based on a variety of models on offer, (3) Discussions on various aspects of staff development inherent in the model the desired changes, (4) Offer a number of ideas that are relevant in developing innovation strategies selected, especially in responding to the problems that arise.

Based on preliminary studies (Grand tour) that the author did in Junior High School 25 Sarolangun, indicated still not optimal empowerment of teachers who do head Junior High School 25 teachers Sarolangun especially in empowering women in their environment. This is evident from the data I get that from 7 female teachers or educational staff for additional positions, only one person female teachers are given authority as a vice-principal in the field of student affairs. Of course it is not in line with that stated in the Qur'an Surah Al Hujarat Clause 13 which means "O all mankind, indeed We have created you (composed) of a male and a female, and made you nations and tribes that ye may 


\section{International Journal of Science and Research (IJSR) \\ ISSN (Online): 2319-7064}

Index Copernicus Value (2013): 6.14 | Impact Factor (2015): 6.391

know each other, verily the noblest among you is the most pious".

The findings of the preliminary study (grand tour) above, it is clear that the heads of Junior High School 25 Sarolangun still regarded as the number two female teachers compared to male teachers. Therefore, in this study, the authors will discuss on the Empowerment of Women Teachers at Junior High School 25 Sarolangun in Improving Quality of Education Junior High School 25 Sarolangun. Therefore the question is "Why Empowerment Environmental female teachers in Junior High School 25 is not optimal? and how the efforts made by the principal to the empowerment of women teachers in Junior High School 25 Sarolangun?

The purpose of this study is to know about the Empowerment of Women Teachers at Junior High School 25 Sarolangun. While the benefits of this research is a science to the author's own and can give contribution to educational practitioners. The focus of this study only discusses the empowerment of women teachers in Junior High School 25 Sarolangun.

\section{Methods}

Researchers used a qualitative descriptive approach. Through this qualitative descriptive approach,

expectedrevealed an idea of the quality, the paradigm of reality and perception research goals without polluted by formal measurement. Qualitative descriptive approach requires data collection on the subject of research. By using the method of data collection are observation, interviews and documentation, researchers can describe about the phenomena that occur in the field.

\section{Data and Discussion}

\subsection{Empowerment through Employment and Duties Teaching at Junior High School 25 Sarolangun}

Empowering teachers are the steps undertaken to improve the quality of teachers themselves, as a whole and improve the quality ofJunior High School 25 in order to compete with other Junior High School. It is, as put forward by the initials $\mathrm{SH}$ headmaster said in giving the task of teaching, I as the principal of equal opportunity for both teachers female teachers and male teachers. But in the empowerment of women teachers at Junior High School 25 Sarolangun this, indeed I admit that in certain fields (title extra) as a representative of student there is only one person of the female teachers in others I've authorized to male teachers, although number of female teachers and men are almost comparable. Therefore, in order to more clearly can be seen in the following table:

\begin{tabular}{|c|c|c|c|}
\hline No & Name & Duty & Gender \\
\hline 1 & Solihin, S. Ag & $\begin{array}{c}\text { Principles/Physical } \\
\text { Education teacher }\end{array}$ & Male \\
\hline 2 & Abu Hanifa, S.H & Citizenship Teacher & Male \\
\hline 3 & Drs. Abdullah. S. Pd & $\begin{array}{c}\text { Vice curriculum / Bahasa } \\
\text { Indonesia teacher }\end{array}$ & Male \\
\hline 4 & Mukhlis, S. Ag & Computer Teacher & Male \\
\hline 5 & Pirwanto, S. Pd & Egglish Teacher & Male \\
\hline 6 & DewiSusnita, S. Ag & Science Teacher & Female \\
\hline 7 & Desniarti, S. Pd & Social science Teacher & Female \\
\hline 8 & RizaAprila, S. Pd & Matematic Teacher & Female \\
\hline 9 & Ahmad Habibi, S. Pd. & Islam Religion Teacher & Male \\
\hline 10 & Ahyat, S. E & Social science Teacher & Male \\
\hline 11 & Sagerta, A. Md & Matematic Teacher & Female \\
\hline 12 & Aninar, S. Pd. I & Art Teacher & Female \\
\hline 13 & Amin Jayadi, S. E.i & Science Teacher & Male \\
\hline 14 & Apendi & Arabic Language Teacher & Male \\
\hline 15 & Nina Afrizah, S. Pd & Science Teacher & Female \\
\hline 16 & MeryWastuti, S. Pd & Counselling Teacher & Female \\
\hline
\end{tabular}

According to the table above, it is known that the female teachers and male teachers nearly balanced that there are 7 and 9 female teacher male teachers including Principal. Therefore, Master Women's empowerment through the task of teaching is in conformity with the expertise possessed by female teachers themselves. As pointed out by the Principal said that the teacher at Junior High School 25 Sarolangun, almost everything is degree (S1), there is only one person who still D-3. For that, I as a leader motivate teachers, in order to improve the competency qualification to a higher level again $(\mathrm{S} 2)$.

Based on the results of the author's observation that the state teacher at Junior High School N 25 Sarolangun is derived from diverse disciplines. This diversity is certainly advantageous for principals to further empower the teachers, especially female teachers. This is due, almost $95 \%$ are undergraduate (S1). But there are still a lot of inequality in the practice of teaching and learning process. There are some teachers who are still teaching not in accordance with scientific competence.

The results of these observations above are supported by a statement from one of the teachers who had the initials SG, saying that my expertise in the field of agriculture, because I D-3 Farms. But I was asked to teach mathematics. Of course this is not my expertise or my competence. However I tried to teach according to the ability that I have, so what I teach can be understood by students.

Statement of one of the teachers who had the initials SG is very contradictory to Law No. 142005 on teacher and lecturer in article 1, paragraph 1, which reads: The teacher should have the competency qualification, competency, and certification. Meanwhile, paragraph 2 reads: there are four teachers are competence pedagogic competence, competence, personality, professional competence and social competence of teachers. Inthis law confirmed that competency qualification to teach in junior high school teachers have to Tier One (S1) and teach according to their

\section{Volume 5 Issue 8, August 2016}




\section{International Journal of Science and Research (IJSR) \\ ISSN (Online): 2319-7064}

Index Copernicus Value (2013): 6.14 | Impact Factor (2015): 6.391

expertise. In addition, PP No.19 of 2005 on National Education Standards on points to three (3) are on Standards for Educational, where teachers teach in junior high school must meet the standards and teaching must be professional.

In connection with the empowerment of female teachers according to the observations of the author, there is one female teacher who is empowered by the principal as the deputy chief of the student. But this compared four existing positions, female teachers only got one position only. This means that female teachers are still in junior high school discriminated by the head 25 Sarolangun. As recognition of one of the teachers who had the initials RA say that I was the only female teachers appointed deputy headmaster of student field. No of principal for this makes the representatives of women teachers. In a meeting earlier this year I was appointed to be deputy head, of course this is the development of my career first gained extra duties in addition to being a teacher.

Seven teachers of women who are, indeed all of civil servants is not everything, but there is still the honorary status of teachers. When viewed from the side of the female honorary dedication of teachers at Junior High School 25 Sarolangun, already over 13 years of service, but has received no proposal from the principal or the attention of the local government to raise the status of honorary become civil servants. But seen from the other side, although not addressed, these female teachers to keep the spirit to serve and make the process of learning and teaching in Junior High School 25 Sarolangun.

To that end, according to the narrative of the principal temporary teacher career development of women is currently being sought and proposed to become civil servants. Moreover, as the principal there is always motivating teachers to participate in the selection of civil servants either through general or special channel (K2). For now, do not just have the identification number of teachers (NUPTK) only, but no follow-up to the fore.

\section{Empowerment Through Competence Enhancement of Qualifications and Training}

Empowerment increased competence qualifications and training are very motivated by the principal to the teachers who teach in Junior High School 25 Sarolangun it. Because of the increased competence of teachers is the responsibility of female teachers themselves, is also the responsibility of the school principal.In addition, the training program became one for teachers to increase knowledge and insight for teachers to better. However, to attend the training not all teachers could follow, because the need is so limited. Then the female teachers there has not been included in the training conducted by the Ministry of National Education and Religious Affairs. Because sometimes female teachers, many reasons when in order to attend the training.

In terms of training to increase knowledge and the balance between the demands of the profession with the ability possessed by the teacher. According to the authors obtained information that the sending of teachers in training activities is a priority program. If there is a teacher who gets the call for training, then the teacher must depart, both held at district and provincial level. Based on data from Junior High School 25 Sarolangun documentation can name the teachers Junior High School 25 Sarolangun who have attended training activities or training either carried out at the district and provincial levels, can be seen in the following table.

\begin{tabular}{|c|c|c|c|c|}
\hline NO & Name & Gender & Year & Explanation \\
\hline 1 & Amin Jayadi, S.E.I & Male & 2013 & 1 subject \\
\hline 2 & Ahmad Habibi, S. Pd,I & Male & 2014 & 1 subject \\
\hline 3 & RizaAprila, S. Pd & Female & 2014 & 1 subject \\
\hline 4 & Ahyat, S.E & Male & 2014 & 2 subject \\
\hline 5 & Pirwanto, S. Pd & Male & 2015 & 1 subject \\
\hline 6 & Amin Jayadi, S. E.I & Male & 2015 & 1 subject \\
\hline \multicolumn{4}{|c|}{ Total } & 7 subject \\
\hline
\end{tabular}

The above table shows that there the last 3 years there are 6 teachers who attended the training, four of them were male and one person is female teachers, at both district, and province. Viewed from the side of the participant sending participants upgrading uneven, nothing had gone through the training of up to two times, while others have not yet been entirely. According to information from the head of Junior High School 25 Sarolangun it was due to request of the uneven field of study, there are subjects that are often implemented training and there are subjects who have never held a training and the school will send a request.

According to the writer's observation training and upgrading program held at Junior High School 25 Sarolangun not been able to address the needs of female teachers to increase their knowledge through this event. This training is actually very much need to remember in order to improve the quality of education at Junior High School 25 Sarolangun. As for the participants uneven turns principals never submitted to the organizers for the training into other subjects other than those held by the organizer, therefore until there is inequity in upgrading and training participants. School principals should organize training to broaden the teachers. The school principal should seek and hold training or the like which held the school by calling the resource, or seek her teachers participate in training activities. There are several factors that a barrier to principals to empower teachers include:

\section{1) Lack of Understanding of Principal Management Empowerment}

Based on observations of the authors in the field, the head of Junior High School 25Sarolangun, not yet fully understand the function of management in the provision of education in schools. School principals tend to implement the activities scheduled by the Department of Education only Sarolangun without having program initiative capable of empowering women teachers optimally.

Managerial problems in school activities can be observed also by the lack of efforts to remedy weaknesses in the process of education activities in schools, especially issues related to human resources (HR) female teachers there. Though these factors lead to weakness overall educational activities, such as those related to the competence and performance of female teachers.

\section{Volume 5 Issue 8, August 2016}




\section{International Journal of Science and Research (IJSR) \\ ISSN (Online): 2319-7064}

Index Copernicus Value (2013): 6.14 | Impact Factor (2015): 6.391

\section{2) Lack of Compensation of Principal}

The compensation has a big influence on efforts to raise the motivation to teachers in developing capabilities. So it is necessary to understand what the compensation will be granted or how such compensation forms must be received by female teachers. Concerning compensation could take the form of direct and indirect compensation. Award or reward as compensation can be distinguished as follows:

\section{a) Direct Compensation}

Direct compensation is a reward or award is called the salary / wages paid to female teachers school regularly, based on a fixed time limit. In line with this definition, a wage or salary. In response to this, another female teacher, said that the limited financial capacity of the school is also making us reluctant to empower themselves achieve career development held by the government. Our ability to financially (salary) competence is very low to support our teachers. Nevertheless, the spirit of our teaching is very high.

Salary mediocre force a teacher to earn extra after work hours. It can lead to have no chance to make preparations to teach by re-reading the material that will be taught tomorrow.. "salaries paid to our female teachers varies, ranging from 175 to 400 thousand per month. It depends on our working hours at this school. Based on interviews with the writer's observation, it is known that the economic factors clearly affecting school teacher empowerment of women in Junior High School25 Sarolangun. It also cannot be separated from culture-oriented work on a salary that is less of motivation to cultivate an attitude of female teachers in the female teachers who are sincere in their duties as a teacher.

\section{b) Indirect Compensation}

Indirect compensation may be giving the profits, either in cash and goods or office. The performance is conducted by the teacher women often get an assessment of the principal. Achievement carved by female teachers should be given a positive response from principals like devotion that has been from the beginning of the establishment of schools to consider occupying a particular position in the school. The award is given it will provide motivation to female teachers. One of the female teachers initials, DS, said that there has never been a special awards or rewards given to us as a female teacher. Current is supplied only for wages and salaries for our teachers' salaries are set in accordance with the committee meeting of BOS funds lane center. And it was with the amount of mediocre, even approaching less.

\section{3) Less motivation of principals}

The motivation of the principal will give a great influence on the behavior of the teacher. Oneteacher initials by RA said to me, the internal factors of the principal in managing faculty is indeed evident from the lack of interest on the principal itself for the innovation of careful planning in the empowerment of women teachers.

\section{4) Lack of School Funding}

Cost is an most important factor in improving the competence of female teachers as empowerment of women teachers. In order for teachers to become professionals, not only necessary motivation to be creative, but it will cost in the implementation of education is necessary. Education funds are quite expensive less reach out to female teachers, but this can be minimized, as claimed by one of the teachers who had the initials HA, the factor that inhibits the competence of female teachers of Junior High School 25 Sarolangun is in terms of financial and infrastructure facilities are inadequate.

Based on the information that the funding issue is still a major factor in the school's head teacher empowering women. Increased competence of every teacher should be coupled with the financial capacity of existing schools. Thus, it should be at least sufficient funds to improve the quality and the quality of teachers in schools.

\section{5) Lack of cooperation with local and provincial government in Teacher Empowerment of Women}

Principals should cooperate with local and provincial governments to empowering female teachers according to its ability and expertise. This is in accordance with Act No. 20 of 2003 on National Education System (Education). As for one of its substance is the realization of the education system as a social institution that is strong and authoritative to empower all citizens of Indonesia developed into a quality human so as to proactively respond to the challenges of the times. One effort to improve the quality of education there is empowerment of women teachers.

The activities of school educational institutions in addition regulated by the government, in fact largely determined by the activity of the principal. Therefore, need the cooperation of the local government in empowering women teachers. This was disclosed principal, that cooperation with local governments and related agencies are certainly very needed. This is because the media and funding limitations that exist in the schools teacher empowerment of women.

One of the female teachers initials, DS, said that the local government is still not providing a response to teachers' empowerment of women. External factors in the rise of women's empowerment of teachers, not in spite of support from various parties, such as local government, and the Ministry of National Education which became the first source for the development and empowerment of women teachers.

\section{6) Efforts will be undertaken by the Principal for the next Women's empowerment program}

Empowerment of women teachers can do to improve morale, encourage professional development, build collaboration and cooperation, creation of conducive working environment, create a program of rewards and punishments, training and development, creating conditions of mutual trust, and promote the active participation of teachers in completing the task in decision-making and most importantly, the principal is able to provide the authority and responsibility professional of female teachers.

According to the narrative of the principal, that he always motivate teachers to improve their capabilities, ranging from teaching himself through books or the media which is an easy and lightweight. Here the female teachers can do with 


\section{International Journal of Science and Research (IJSR) \\ ISSN (Online): 2319-7064}

Index Copernicus Value (2013): 6.14 | Impact Factor (2015): 6.391

limited time and funds though. In this case, the female teachers can utilize the books or the media as provided in the library, school or bookstore on matters related to his specialty or general knowledge that can add insight. Recognizing the limitations and lack of professional female teachers, principals try his best to motivate female teachers there. With no limitations to always instructive to read. Books that there in library I feel I have enough for that.

Learning itself is lightweight and simple way to develop the professionalism of female teachers. However, it is becoming very difficult to be implemented due to lack of awareness of female teachers to develop skills through reading and given the many administrative tasks, so that female teachers cannot use the time well.

In addition to the motivation to learn, the head of Junior High School 25 Sarolangun also motivate teachers to do research or to continue their studies both S1 and S2 to the development of long-term capabilities. As pointed out by the Principal, said that to make scientific papers in Junior High School 25 Sarolangun, not entirely female teachers who could afford only one or two people who have followed this. This is evidenced when there is competition between PKBM manufacture of paper, this is where the female teachers make scientific papers. Although time was lost, at least we humiliation of women teachers who are able to write.

Awareness to write off many female teachers to write on issues of education and teaching, including one of the methods to improve their professional ability in give concepts and ideas in written form. Besides providing benefit to authors, this activity will also provide benefits for future readers. To make the paper as professional achievements necessary support conditions and adequate facilities, the ability, and opportunity as well as continuously from female teachers in Junior High School 25 Sarolangun. Therefore, every female teachers should be aware and willing to train himself if he really wanted to setting up their creativity through writing.

The motivation for continuing education has also been submitted by the principal. Best effort teachers to take the catch is to go to college for continuing education levels. By continuing education levels expected female teachers can increase their knowledge and acquire new information in education. So that the teacher knows science education and are capable of projecting futuredevelopment.

Furthermore, it is also necessary to realize that empowerment covers various aspects including social, economic, political, and psychological. Social empowerment is an attempt how to obtain access to information, access to knowledge and skills, access to participate. Economic empowerment means is having the ability economically to make ends meet. Political empowerment is having access to decision-making processes that affect their future. Medium psychological empowerment is an attempt how to build confidence for them to be empowered.

When viewed in Islamic studies, leadership is a process of influencing and directing the employees to do the work that was assigned to them. Another opinion put forward also
bySagala (2004), that leadership is a subject of great human desire to mobilize the potential of the organization, leadership is also one of the mutually explanatory popular success or failure of an organization. This means that an organization Institution where otherwise successful and unsuccessful primary deciding factor is leadership. Strong leadership and tough and has a strong commitment in implementing the organization's program is essential in an organization.

Another explanation on another paragraph, letter of $A n$ Nahal, paragraph 90. It means "God tells (you) to be fair and do good, giving to kinsfolk, and God forbid of indecency, crime and hostility. He teaches you, that ye may take heed". Islam has introduced the concept of gender relations by reference to the substantive passages leading to the destination once the Shari'ah, among others, is the realization of equality and justice. Therefore, women have an equal right to be a leader or empowered. No exception of female teachers who have the same position with others in the organization of education at Junior High School 25 Sarolangun

\section{Conclusion}

Based on the description that has been stated above, the writer can draw conclusions as follows:

Empowerment of women teachers in Junior High School 25 Sarolangun by the school principal is still not on par with male teachers, it can be seen from the additional positions and training is only one female teacher only. Of course it is indicated that the principal of the view that the ability of female teachers is still lower than the ability of men. In addition, the principal still regard women teachers lack the confidence to be empowered in strategic positions equivalent to men, who are less able to compete with men.

\section{Recommendation}

1) Head of school teachers do not discriminate against women, should empower women teachers on par with male teachers both in positions and include training women teachers to take part in both the Kapupaten as well as in the province.

2) Female teachers in Junior High School 25 Sarolangun should be confident, and be not entangled in dideskriminasikan by men, show that the ability of women the same as men.

\section{References}

[1] Depag, Al-Qur'an dan Terjemah, Jakarta: Pengadaan Al-Qur'an, 1986

[2] Edgar Wille, Quality: Achieving Exelence, London: Century Bussiness, 1992

[3] Grisay A dan Mahlck, The quality of education in Developing:a Preview of Same Research Studies and Policy Documents, Paris: IIEP

[4] Hadari Nawawi, Manajemen Strategik, Yogyakarta: Gadjah Mada University Pres, 2003 


\section{International Journal of Science and Research (IJSR) \\ ISSN (Online): 2319-7064}

Index Copernicus Value (2013): 6.14 | Impact Factor (2015): 6.391

[5] Kemendiknas, Undang-undang No.14 tahun 2005 Tantang Guru dan Dosen

[6] Kemendiknas Peraturan Pemerintah No.19 Tahun 2005 Tentang Standar Nasional Pendidikan

[7] Kemendikbud, Bahan Pembelajaran Utama: Pengelolaan Pendidik dan Tenaga Kependidikan, Jakarta, 2012

[8] Kadarisman, Manajemen Pengembangan Sumberdaya Manusia, Jakarta: Raja Grafindo, 2013

[9] Maisah, Manajemen Pendidikan, Jakarta, Gaung Persada Press Group, 2013

[10] Mulyasa, Manajemen Dan Kepemimpinan Kepala Sekolah, Jakarta:Bumi Aksara, 2013

[11]Lias Hasibuan, Melejitkan Mutu Pendidikan, Jambi: Safa Projek, 2008

[12]Nanang Fatah, Sistem Penjaminan Mutu Pendidikan dalam Konteks Penerapan MBS, Bandung: Remaja Rosdakarya, 2013

[13] YB. Irianto, Manajemen Mutu Terpadu (MMT) Konsep dan Strategi Implementasi "TQM" dalam Lembaga Pendidikan Bandung, Bandung: FIP-KIP, 1997

[14]R. Rayne Pace dan Don F. Faules, Komunikasi Organisasi, Bandung : Remaja Rosakarya, 2006

[15] Suyadi Prawirosentono, Filosofi Baru Tentang Manajemen Mutu Terpadu Abad 21 : Kiat Membangun Bisnis Yang Kompetitif, Jakarta: Bumi Aksara, 2007

[16] Suparno Eko Widodo, Manajemen Pengembangan Sumberdaya Manusia, Jakarta: Jaya Media, 2014 